Mathematics Department of the Polytechnic, will be used for the following purposes : (1) as a service to users in industry and commerce who are invited to discuss their problems with the computer staff and use time on the computer; a fee will be charged for this latter service; (2) for the training of students in the use of digital computers. It is intended that every student of the Polytechnic who is studying for a B.Sc. degree in mathematics, physics, chemistry, engineering or economics, and every student studying for a diploma in technology or a higher national certificate with endorsements, will have an opportunity to write programmes for and to operate the computer; (3) as an aid to research by members of the staff and postgraduate students of the Polytechnic and other educational establishments.

\section{Liverpool Observatory and Tidal Institute}

THe Liverpool Observatory and Tidal Institute, which for many years has been administered jointly by the Morsey Docks and Harbour Board and the University of Liverpool, is to become the sole responsibility of the University. The Observatory was founded in 1845 by the Liverpool Dock Trustees, and the Mersey Docks and Harbour Board, on its formation in 1858, took over the operation of the Observatory. The main reason for its establishment was the absence of knowledge at that time concerning nautical astronomy and even the most elementary details of correct determination of chronometer-rates and meteorology. The present Observatory building at Bidston was erected in 1864. The Observatory continued largely as an astronomical and meteorological institution until the death in 1928 of the then director, Mr. Plummer, an officer of the Mersey Docks and Harbour Board. For some years prior to this there had been close association with the Tidal Institute which had been founded by the University of Liverpool, largely through the influence of the late Mr. Charles Booth, a Liverpool shipowner, with whom was associated Prof. J. Proudman, and from January 1, 1929, the Board and the University agreed to combine the tidal work of the Institute and the work of the Observatory at Bidston under the name "The Liverpool Observatory and Tidal Institute", administered by a joint committee of both bodies. Since that time the joint committee has been extended to include representatives of the Admiralty and the National Institute of Oceanography. In addition to the work of tidal prediction, for which it is famous, the Institute has built up an international reputation in the scientific world and is deeply involved in the study of major problems such as the determination of mean sea-level and the investigating of storm surges as well as other matters involving geophysics and oceanography. The activities of the Institute are now far wider than was envisaged when the joint committee was set up in 1929, so tho Dock Board has handed over its responsibilities to the University of Liverpool. For the time being the Observatory will be administered by the acting director, Dr. J. R. Rossiter, following the retirement of Dr. A. T. Doodson (see Nature, November 19, p. 625).

The Netherlands Universities Foundation for International Co-operation

THE organization known as the Netherlands Universities Foundation for International Co-operation was founded in 1952 to promote international co-operation in academic life at universities and elsewhere. It seeks to do this by functioning as a centre for consultations among institutes and persons at. home and abroad; by encouraging the founding and maintaining of special forms of international education in the Netherlands; by keeping those abroad informed about university life and scientific activity in the Netherlands and vice versa; and by lending more general assistance with regard to measures and facilities on behalf of international academic and scientific contact and exchange. The Board of Governors is composed of representatives of all Dutch universities and the honorary prosident is H.R.H. The Prince of the Netherlands. The Foundation furthers international cultural exchanges in various ways, among others by founding institution.s and courses of education on an international basis. Here it is active in a field which has been reconnoitred inadequately, and which presents many problems. It is aware of the need to subject this field of activity to further investigation. As yet, only a modest beginning has been made on this work, but individual research workers have been given commissions to form teams of experts to study comparative education; the problems of inter-cultural communications ; the difficulties students from abroad encounter in adapting themselves in the Netherlands; and the evaluation of study in a foreign country. Another subject receiving close attention is European integration, the gradual achievement of which is believed to depend to a considerable extent on voluntary international co-operation within the world of higher education and research, and on the attention given to European affairs in individual institutions of higher learning. A pamphlet prepared by the Foundation describes the detailed work of the organization (Netherlands Universities Foundation for International Co-operation (NUFFIC): Aims and Activities. Pp. 16. The Hague: Netherlands Universities Foundation for International Co-operation, 1960).

\section{The Mauritius Institute}

THE annual report of the Mauritius Institute for 1958 notes the increasing demand on the library services, which include a scientific section, which has been combined with the Library of the Royal Society of Arts and Sciences to form a nucleus of works on natural history and biology (Pp. $\mathrm{i}+27$. Port Louis : Mauritius Institute, 1959. 25 cents). The report includes brief descriptions of the various sections of the Natural History Museum of Port Louis, which was reopened to the public in 1957, as well as of the Historical Museum. A function of the Mauritius Institute is to build regional collections and have them accurately identified, and the annual reports of the Institute should be particularly useful to workers on any group of the Mascarene fauna or flora. This Museum report includes somo notes on research in zoology, entomology and botany, a list of publications during the year and also lists of Museum accessions, additions to the fauna of the Mascarene Islands and of library acquisitions. Similar lists are given in the annual report of the Mauritius Institute for 1959, to which are also appended a note on recent advances in the study of the fauna of the Mascarene Islands and one on the Special Collection of the Mauritius Institute Library dealing with the Mascarenes, Madagascar and the Indian Ocean (Pp. ii +28 . Port Louis: Mauritius Institute, 1960. 50 cents). 